\title{
Ascorbic Acid Suppresses House Dust Mite-Induced Expression of Interleukin-8 in Human Respiratory Epithelial Cells
}

\author{
An Jun Lee, Joo Weon Lim, Hyeyoung Kim \\ Department of Food and Nutrition, BK 21 FOUR, College of Human Ecology, Yonsei University, Seoul, Korea
}

\begin{abstract}
House dust mite (HDM) is one of the significant causes for airway inflammation such as asthma. It induces oxidative stress and an inflammatory response in the lungs through the release of chemokines such as interleukin-8 (IL-8). Reactive oxygen species (ROS) activate inflammatory signaling mediators such as mitogen-activated protein kinases (MAPKs) and redox-sensitive transcription factors including NF-kB and AP-1. Ascorbic acid shows an antioxidant and anti-inflammatory activities in various cells. It ameliorated the symptoms of HDM-induced rhinitis. The present study was aimed to investigate whether HDM could induce IL-8 expression through activation of MAPKs, NF- $\mathrm{KB}$, and AP-1 and whether ascorbic acid could inhibit HDM-stimulated IL-8 expression by reducing ROS and suppressing activation of MAPKs, NF- $\mathrm{KB}$, and AP-1 in respiratory epithelial $\mathrm{H} 292$ cells. $\mathrm{H} 292$ cells were treated with $\operatorname{HDM}(5 \mu \mathrm{g} / \mathrm{mL})$ in the absence or presence of ascorbic acid (100 or $200 \mu \mathrm{M})$. HDM treatment increased ROS levels, and activated MAPKs, NF-kB, and AP-1 and thus, induced IL-8 expression in H292 cells. Ascorbic acid reduced ROS levels and inhibited activation of MAPKs, NF- $\mathrm{KB}$ and AP-1 and L-8 expression in $\mathrm{H} 292$ cells. In conclusion, consumption of ascorbic acid-rich foods may be beneficial for prevention of HDM-mediated respiratory inflammation by suppressing oxidative stress-mediated MAPK signaling pathways and activation of NF-kB and AP-1.
\end{abstract}

Key Words House dust mite, Ascorbic acid, Interleukin-8, Respiratory epithelium

\section{INTRODUCTION}

House dust mite (HDM), which often instigates airway inflammation and hence incites the development of asthma and allergic symptoms worldwide, has been well known as momentous indoor sensitizing factor. House dust mite is a universal companion in human habitation and feeds on organic detritus like flakes of shed human skin [1]. In Korea, there are about twenty species of house dust mite; Dermatophagoides farinae, Dermatophagoides pterronyssinus, Tyrophagus putrescentiae, Euroglyphus maynei, Glycyphagus destructor, and so on. Among them, Dermatophagoides farinae (D. farinae), so called American house dust mite, is a dominant species [2]. Multiple lines of evidence suggest that exogenous proteases (allergens) from the $D$. farinae have direct proinflammatory effect in the respiratory tract. Proteolytic activities of these allergens stimulate the release of potent cytokines and chemokines from human airway epithelium [3]. Yi et al. [4] showed that HDM allergen Der $\mathrm{f} 1$ ( $D$. farinae Group 1 allergen), the papain-like cysteine protease, induces interleukin-8 (IL-8) expression in human basophilic cells through generation of reactive oxygen species (ROS) and subsequent activation of extracellular signal-regulated kinase $(E R K) / p 38$ signal pathways. They suggested that Der $\mathrm{f} 1$-induced IL-8 secretion may account for allergic inflammation independent of immunoglobulin E antibodies. HDM-induced airway inflammation is associated with ROS production in human bronchial epithelial cells [5] and in neutrophils [6]. Therefore, reducing ROS may be beneficial to inhibit HDM-induced inflammation by suppressing expression of pro-inflammatory cytokines such as IL-8.

IL-8, a CXC neutrophil chemotactic and activating peptide, is an important mediator of the inflammatory response. The IL-8 secretion is stimulated by various stresses such as bacteria, oxidants, bacterial lipopolysaccharide, and pro-inflammatory cytokines [7-9]. Patients with status asthmaticus

Received March 1, 2021, Revised March 12, 2021, Accepted March 16, 2021

Correspondence to Hyeyoung Kim, E-mail: kim626@yonsei.ac.kr, https://orcid.org/0000-0002-7019-917X

Check for updates 
exhibit striking increase of IL-8 and neutrophils in the airways. IL-8 is also found in bronco-alveolar lavage fluid and serum from patients with asthma [10]. These findings indicate that IL-8 mediates airway inflammation and innate immunity. In addition, it may be a crucial mediator of human respiratory inflammation such as asthma.

Expression of IL-8 gene, which is stimulus-dependent, is generally controlled at the transcriptional level. There is a promoter element which harbours the $\mathrm{NF}-\kappa \mathrm{B}$ site in $\mathrm{LL}-8$ gene $[11,12]$. NF-кB and AP-1 are the pleiotropic transcription factors that regulate the transcription of genes, which responds to immune or inflammatory signals in lung epithelial cells [13]. HDM increased IL-8 levels by activation of NF-кB in nasal epithelial cells [14] and bronchial epithelial cells [15]. Several studies demonstrated that phosphorylation of mitogen-activated protein kinases (MAPKs) including ERK, c-Jun $\mathrm{NH} 2$-terminal kinase (JNK), and p38 increased the activity of $\mathrm{NF}-\mathrm{KB}$ in the promoter region of IL-8 gene [16]. MAPKs have a vital role in the release and expression of IL-8 in response to the stimulation by Mycoplasma pneumoniae [17], German cockroach extract [18], and respiratory syncytial virus in airway epithelial cells [19]. HDM increased IL-8 via activation of ERK in respiratory epithelial cells [20]. ROS are considered as the activators for MAPK signaling and transcription factors $\mathrm{NF}-\kappa \mathrm{B}$ and AP-1 in lung and airway epithelial cells $[21,22]$. Therefore, reducing ROS may be a rational strategy to prevent HDM-induced cytokine expression in respiratory system.

Ascorbic acid, so called vitamin $\mathrm{C}$, has diverse functions for the maintenance of human health. As an antioxidant, ascorbic acid has protective effects against inflammatory disorders such as common cold [23] and pneumonia [24]. There are relatively few studies on the effect of ascorbic acid on HDM-associated airway inflammation. Anderson et al. [25] demonstrated that 6 month-supplementation with ascorbate (1 $\mathrm{g} /$ day) under standard therapy to ten children with bronchial asthma (caused by allergens from HDM) improved cellular immune function, determined by neutrophil chemotaxis and lymphocyte mitogen-induced transformation. Tongtako et al. [26] examined whether exercise training and ascorbic acid supplementation are effective adjuvant treatments in the management of symptoms in HDM-induced allergic rhinitis patients. After 8 weeks, both exercise alone and exercise combined with supplementation of ascorbic acid increased peak aerobic capacity and peak nasal inspiratory flow, and exhibited significantly decreased rhinitis symptoms, nasal blood flow, malondialdehylde levels, and nasal secretion of IL-4.

The purpose of the study is to investigate whether HDM induces expression of IL-8 through regulation of MAPKs, NF$\kappa \mathrm{B}$, and $\mathrm{AP}-1$, and whether ascorbic acid has an inhibitory effect on HDM-stimulated IL-8 expression by reducing ROS levels and suppressing the activation of MAPKs, NF-KB, and AP-1 in respiratory epithelial $\mathrm{H} 292$ cells.

\section{MATERIALS AND METHODS}

\section{Cell line, house dust mite, and reagents}

Human respiratory epithelial (NCl-H292) cells were purchased from the American Type Culture Collection (Manassas, VA, USA) and cultured as previously described [27]. House dust mite $D$. farinae extract (CE-DF-101006001) was purchased from Arthropods of Medical Importance Resource Bank (AMIB), Yonsei University College of Medicine, Seoul, Korea. It was dissolved in phosphate-buffered saline (PBS) and then stored at $-80^{\circ} \mathrm{C}$. Ascorbic acid (Sigma-Aldrich, St. Louis, MO, USA) was dissolved in sterilized water.

\section{Experimental protocol}

For time-course experiments, the cells were treated with HDM $(5 \mu \mathrm{g} / \mathrm{mL})$ and incubated for 60 minutes (for determination of MAPKs), 10 hours (for determination of IL-8 mRNA level), or 24 hours (for determination of IL-8 in the medium). For ascorbic acid experiment, the cells were treated with HDM $(5 \mu \mathrm{g} / \mathrm{mL})$ in the absence or presence of ascorbic acid (100 or $200 \mu \mathrm{M}$ ) for 15 minutes (for determination of MAPKs), 30 minutes (for measuring ROS levels and activities of NF$\kappa \mathrm{B}$ and $\mathrm{AP}-1$ ), and 2 hours (for determination of IL-8 mRNA level), and 10 hours (for determination of IL- 8 in the medium).

For the determination of IL-8 mRNA and protein levels and ROS levels, the cells $\left(3 \times 10^{5}\right.$ cells/well), in 6 -well plate, were cultured for indicated time periods. For the determination of MAPKs and activities of NF- $\mathrm{kB}$ and AP-1, the cells $\left(2 \times 10^{6}\right.$ cells) were seeded in $10 \mathrm{~cm}$ culture dish and cultured for indicated time periods.

\section{RT-PCR analysis of IL-8 mRNA expression}

Total RNA were isolated by TRI reagent (RNA/DNA/Protein isolation reagent; Molecular Research Center, Inc., Cincinnati, $\mathrm{OH}$, USA). Total RNA was reverse transcribed into cDNA by reverse transcription process using moloney murine leukemia virus reverse transcriptase and random primer (Promega, Madison, WI, USA) with conditions at $23^{\circ} \mathrm{C}$ for 10 minutes, $37^{\circ} \mathrm{C}$ for 60 minutes, and $95^{\circ} \mathrm{C}$ for 5 minutes. The resulting CDNAs were used for RT-PCR analysis of IL-8 and $\beta$-actin. Sequences of IL-8 primers were $5^{\prime}$-ATGACTTCCAAGCTGGCCGTGGCT-3' for forward primer and 5'-TCTCAG CCCTCTTCAAAAACTTCT-3' for reverse primer, giving a 297 bp PCR product. For $\beta$-actin, the forward primer was 5'-ACCAACTGGGACGACATGGAG-3' and the reverse primer was 5'-GTGAGGATCTTCATGAGGTAGTC-3', giving a 349 bp PCR product. The cDNA was then amplified by 28 cycles with denaturation at $95^{\circ} \mathrm{C}$ for 15 seconds, annealing at $60^{\circ} \mathrm{C}$ 15 seconds, and extension at $72^{\circ} \mathrm{C} 45$ seconds. $\beta$-actin gene was amplified in the same reaction to serve as the reference gene. After amplication, PCR products were separated on $1.5 \%$ agarose gels and visualized by a UV transillumination. 


\section{ELISA for IL-8 protein level}

The culture mediem were centrifuged at $13,000 \times g$ for 5 minutes and then collected for measuring IL- 8 levels. The level of IL-8 in the medium was determined by using ELISA kit (Biosource International, Camarillo, CA, USA) following manufacturer's instructions.

\section{Electrophoretic mobility shift assay (EMSA) and Western blotting}

Whole cell extracts and nuclear extracts were prepared by the method described previously [28]. NF-kB-DNA binding activity and AP-1-DNA-binding activity were determined by EMSA for nuclear extracts flowed by our previous study [28]. For Western blot analysis of MAPKs, whole cell extracts (30 to $60 \mu \mathrm{g}$ protein/lane) were subjected to $12 \%$ SDS-polyacrylamide gel electrophoresis and transferred to nitrocellulose membranes (Amersham Biosciences, Buckinghamshire, UK) by electroblotting. Membranes were blocked and the proteins were detected with antibodies for p38 (1:500, CS-9212; Cell Signaling Technology, Beverly, MA, USA), p-p38 (1:300, SC7975; Santa Cruz Biotechnology, Dallas, TX, USA), ERK1/2 (p44/p42) (1:500, CS-9102; Cell Signaling Technology), p-ERK1/2 (1:300, SC-7383; Santa Cruz Biotechnology),
JNK2/1 (p54/p46) (1:500 to 1,000, CS-9252; Cell Signaling Technology), and p-JNK2/1 (1:500, CS-9252; Cell Signaling Technology), diluted in TBS with Tween 20 (TBS-T) containing $3 \%$ dry milk, and incubated overnight at $4{ }^{\circ} \mathrm{C}$. After washing with TBS-T, primary antibodies were detected using horseradish peroxidase-conjugated secondary antibodies (anti-rabbit, anti-mouse), and visualized by the enhanced chemiluminescence detection system (Santa Cruz Biotechnology) [28].

\section{Determination of ROS levels}

The cells were treated with $10 \mu \mathrm{g} / \mathrm{mL}$ 2,7-dichlorofluorescein diacetate (DCF-DA; Sigma-Aldrich) and incubated in 5\% $\mathrm{CO}_{2} / 95 \%$ air at $37^{\circ} \mathrm{C}$ for 30 minutes. After incubation, the medium was removed, and the cells were washed with PBS. The fluorescence intensity of the de-esterified product, 2,7-dichlorofluorescein in the cells (in 6-well plates) was measured at $522 \mathrm{~nm}$ (excitation at $498 \mathrm{~nm}$ ) with a Victor 5 multi-label counter (PerkinElmer Life and Analytical Sciences, Boston, MA, USA). Intracellular ROS levels were normalized to the cell numbers.
A
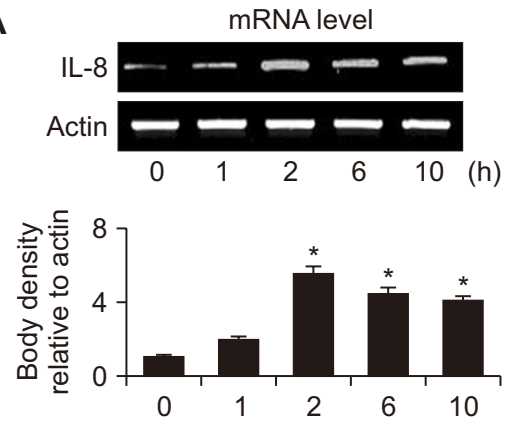

(h)

C

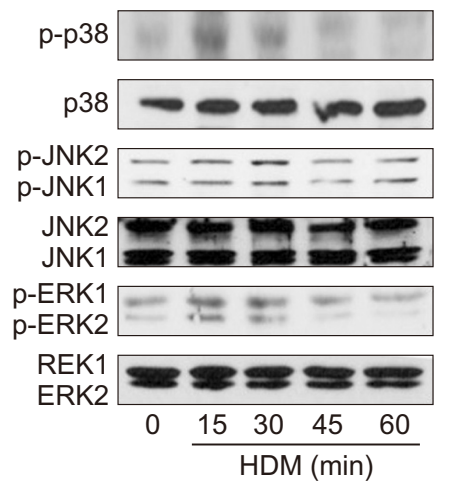

B

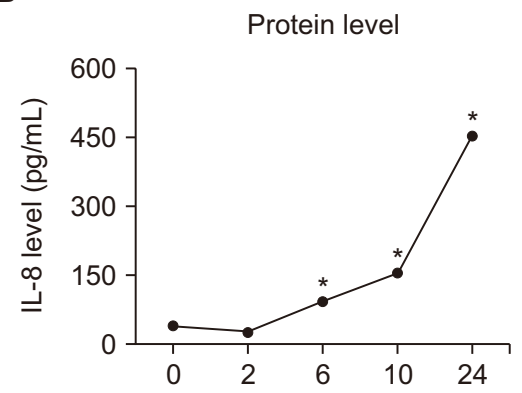

(h)
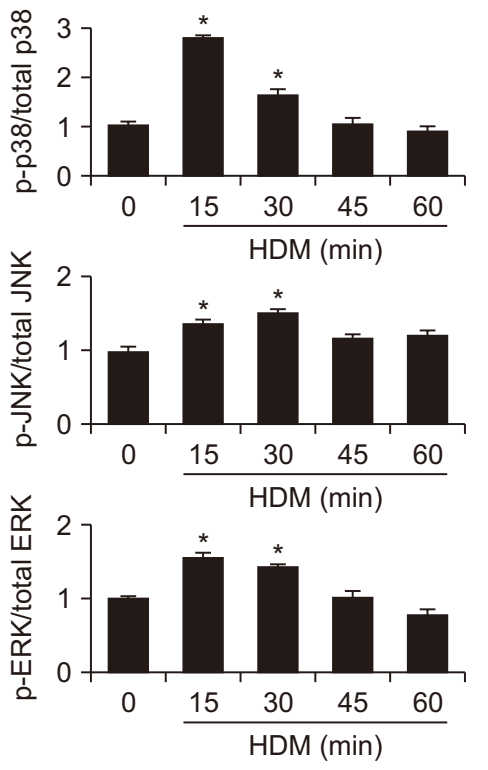

Figure 1. Interleukin-8 (IL-8) expression and activation of mitogen-activated protein kinases (MAPKs) in house dust mite (HDM)stimulated $\mathrm{H} 292$ cells. The cells were stimulated with HDM $(5 \mu \mathrm{g} /$ $\mathrm{mL}$ ) for the indicated time periods. (A, B) Expression of IL-8 mRNA and protein levels in the medium were determined by RT-PCR analysis and ELISA, respectively. (C) Levels of phosphorylated or total form of extracellular signal-regulated kinase (ERK)1/2, C-Jun NH2-terminal kinase (JNK)2/1 and p38 were determined by Western blot analysis. The ratios of phosphorylated form to total form of ERK, JNK and p38 were determined by densitometric analysis of each protein. The density ratio at 0 minute was considered as 1. Data are expressed as mean $\pm \mathrm{SE}$. For each experiment, the number of samples in each group was 4 . ${ }^{*} P<0.05$ vs. 0 minute. 


\section{Statistical analysis}

The statistical differences were determined using one-way analysis of variance and Newman-Keul's test. All data are expressed as mean \pm standard error (SE) of four different experiments. For each experiment, the number of samples in each group was 4 ( $n=4$ per each group). A value of $P<0.05$ was considered statistically significant.

\section{RESULTS}

To investigate whether HDM could induce IL-8 expression, cells were incubated with $5 \mu \mathrm{g} / \mathrm{mL}$ HDM for indicated time periods. As shown in Figure 1A and 1B, HDM induced expression of IL-1 mRNA and its protein production, respectively in a time-dependent manner. Figure $1 \mathrm{C}$ showed that levels of phosphorylated p38, JNK2/1, and ERK1/2 were increased upon HDM exposure. Total forms of p38, JNK2/1, and ERK1/2 were not changed by HDM treatment. These re- sults indicate that HDM activates MAPKs signaling pathway in $\mathrm{H} 292$ cells.

For the effect of ascorbic acid on HDM-induced IL-8 expression in $\mathrm{H} 292$ cells, the cells were treated with ascorbic acid and then stimulated with HDM for 2 hours (mRNA level) and 10 hours (protein release in the medium). As shown in Figure $2 \mathrm{~A}$ and $2 \mathrm{~B}$, ascorbic acid concentration-dependently inhibited HDM-induced expression of IL-8 at both mRNA and protein levels, respectively in $\mathrm{H} 292$ cells.

Figure 2C showed that HDM-induced phosphorylation of p-38, JNK2/1, and ERK1/2 was also suppressed by ascorbic acid. Total forms of MAPKs were not affected by either HDM or ascorbic acid in $\mathrm{H} 292$ cells. These results indicate that p38, JNK2/1, and ERK1/2 may be upstream signaling molecules responsible for HDM-induced IL-8 expression, which is reduced by ascorbic acid.

Since ROS mediate activation of transcription factors NF$\kappa \mathrm{B}$ and $\mathrm{AP}-1$ which regulates induction of IL-8 expression,
A

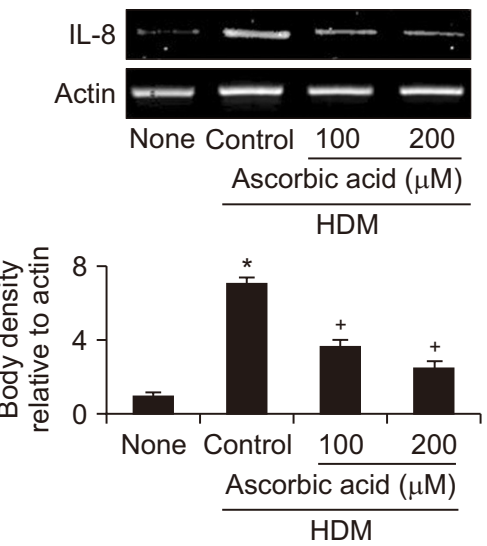

C

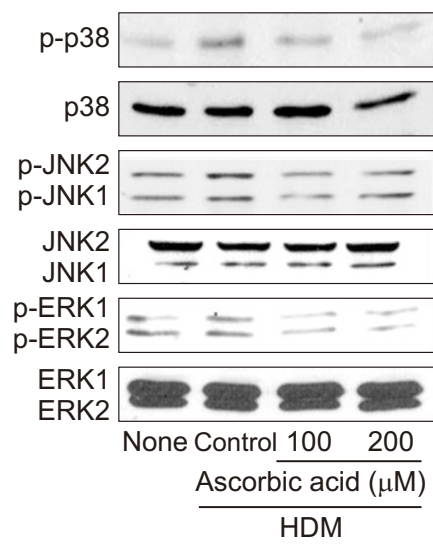

B

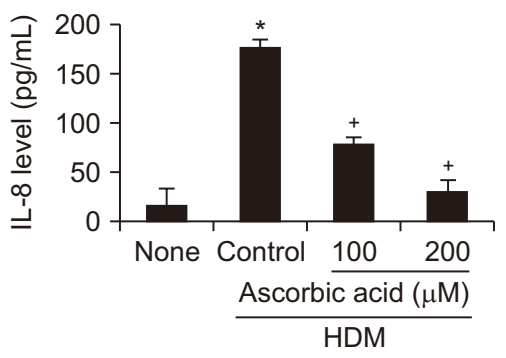

Figure 2. Effect of ascorbic acid on interleukin-8 (IL-8) expression and activation of mitogen-activated protein kinases (MAPKs) in house dust mite (HDM)-stimulated $\mathrm{H} 292$ cells. The cells were treated with or without ascorbic acid and stimulated with $\mathrm{HDM}(5 \mu \mathrm{g} / \mathrm{mL})$ for 2 hours $(A$, IL-8 mRNA expression), 10 hours (B, IL-8 protein leve in medium), or 15 minutes (C, protein levels of MAPKs). (A, B) Expression of IL-8 mRNA and its protein secretion in the medium were determined by RT-PCR analysis and ELISA, respectively. (C) Levels of phosphorylated or total form of extracellular signal-regulated kinase (ERK)1/2, c-Jun NH2-terminal kinase (JNK)2/1 and p38 were determined by Western blot analysis. The ratios of phosphorylated form to total form of ERK1/2, JNK2/1 and p38 were determined by densitometric analysis of each protein. The density ratio of untreated cells (none) was set as 1 . Data are expressed as mean \pm SE ( $\mathrm{n}=4$ per each group). ${ }^{*} P<0.05$ vs. untreated cells (none); ${ }^{\dagger} P<0.05$ vs. HDM control (cell treated with HDM alone). 
DNA binding activities of NF-кB or AP-1 were determined in HDM-stimulated cells in the absence or presence of ascorbic acid. As shown in Figure 3, exposure of $\mathrm{H} 292$ cells to HDM for 30 minutes increased ROS levels and activities of NF-kB and $A P-1$, which were inhibited by ascorbic acid treatment in a concentration-dependent manner. These results indicate that ascorbic acid may inhibit HDM-induced IL-8 expression by suppressing ROS-mediated activation of these transcription factors.

\section{DISCUSSION}

The human respiratory epithelium constitutes the lining of the airway, extending from the nasal cavity through the branching respiratory tree to the terminal air sacs of the lungs. It acts as a physical barrier by filtering and conditioning the air we breathe. Together, respiratory epithelium is a critical controller of local airway inflammation because of its capacity to synthesize a variety of mediators including cytokines [29]. HDM is an environmental cause of inflammation diseases which are originated from respiratory epithelium such as asthma. Allergens from HDM have been shown to incite the expression of several cytokines such as IL-8 in alveolar epithelial cells

\section{A}
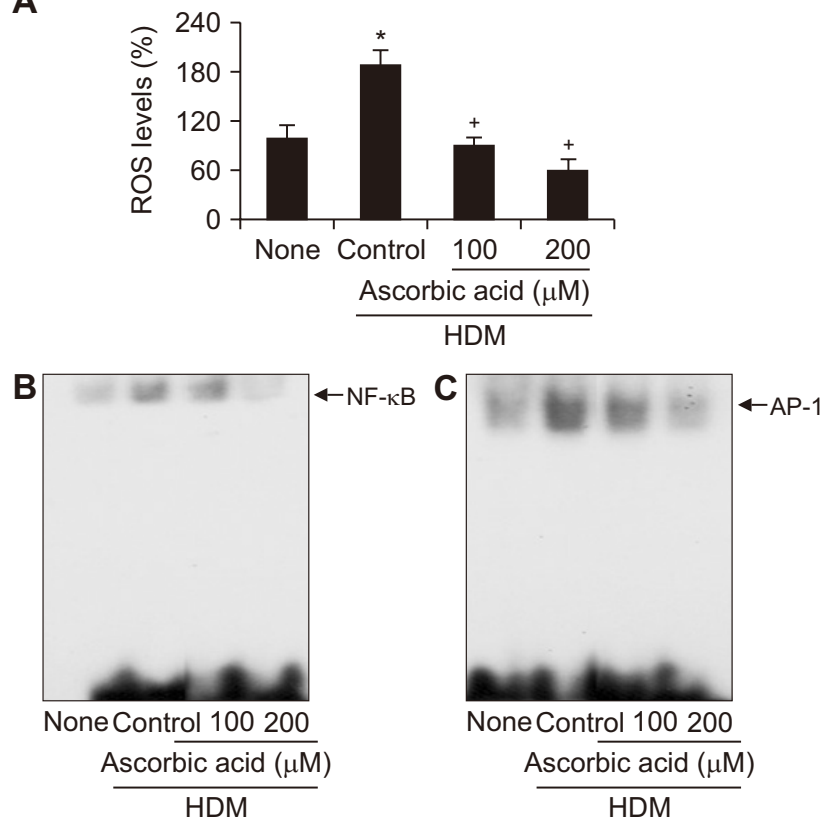

Figure 3. Effect of ascorbic acid on house dust mite (HDM)-induced increase in ROS and activation of NF-KB and AP-1 in H292 cells. The cells were treated with ascorbic acid and stimulated with HDM for 30 minutes. (A) reactive oxygen species (ROS) levels were determined dichlorofluorescein (DCF) fluorescence. The level of untreated cells (none) was set as 100 . Data are expressed as mean \pm SE. For each experiment, the number of samples in each group was 4 . $(B, C)$ DNA-binding activities of NF-KB and AP-1 in nuclear extracts were determined by EMSA. ${ }^{*} P<0.05$ vs. untreated cells (none); ${ }^{\dagger} P<0.05$ vs. HDM control (cell treated with HDM alone).
[30]. IL-8 expression is mediated by transcription factors such as NF-kB $[11,12]$ and $A P-1[31,32]$. It has been shown that HDM induces NF- $\kappa B$-mediated IL-8 expression in lung alveolar A549 cells [33] and eosinophils [34]. Osterlund et al. [35] demonstrated that non-proteolytic HDM allergen Der $\mathrm{p} 2$ ( $D$. pteronyssinus Group 2 allergen) induced IL-8 expression in A549 cells which was dependent on NF- $\mathrm{KB}$ and MAPK activation. Therefore, inhibiting activation of, MAPKs, NF- $\kappa B$ and AP-1 may be helpful to prevent HDM-associated respirator inflammation.

Pan et al. [36] showed that HDM-induced expression of IL-6 and IL-8 cytokines was mediated via epidermal growth factor receptor (EGFR) signaling in normal bronchial epithelial BEAS-2B cells. HDM allergen Der $\mathrm{p} 1$ (D. pteronyssinus Group 1 allergen) induced expression of IL-8 through protease activated receptor-2 (PAR-2) in nasal epithelial cells [14]. HDM allergen Der p 5 stimulates airway epithelial cells through a toll-like receptor 2 (TLR2) pathway [37]. These results indicate that inflammatory signaling may be dependent on HDM allergens. Recently, Zhang et al. [38] showed that HDM elevated the levels of TGF-beta3 (TGF- $\beta 3$ ) which was accompanied by increased ROS production in airway epithelial cells. They also found that NADPH oxidase 4 (NOX4) expression was induced in TGF- $\beta 3$-stimulated epithelial cells. Moreover, HDM increased ROS in a NOX4-dependent manner with concomitant enhancement of mucin secretion in epithelial cells. Therefore, inhibition of NOX4 may be one of the treatment strategies for HDM-induced respiratory inflammation. Further study should be performed to determine whether ascorbic acid suppresses NOX4, EGFR, PAR-2, or TLR2 signaling in respiratory epithelial cells exposed to allergens other than HDM.

In summary, our present study demonstrates that HDM-induced IL-8 expression is mediated with MAPKs ( $p-38$, JNK, and $E R K), N F-\kappa B$ and $A P-1$ in human respiratory epithelial H292 cells. Ascorbic acid suppressed HDM-induced expression of IL-8 in $\mathrm{H} 292$ cells by inhibiting phosphorylation of MAPKs, and suppressing NF-кB and AP-1 activation in H292 cells. Reducing ROS by ascorbic acid may inhibit the activation of MAPKs and transcription factors NF-kB and AP-1 to induce IL-8 expression in respiratory epithelial cells. Therefore, consumption of ascorbic acid-rich foods may be beneficial for preventing HDM-associated respiratory inflammation.

\section{CONFLICTS OF INTEREST}

No potential conflicts of interest were disclosed.

\section{ORCID}

An Jun Lee, https://orcid.org/0000-0002-7585-580X

Joo Weon Lim, https://orcid.org/0000-0001-7483-3820

Hyeyoung Kim, https://orcid.org/0000-0002-7019-917X 


\section{REFERENCES}

1. Platts-Mills TA, Vervloet D, Thomas WR, Aalberse RC, Chapman MD. Indoor allergens and asthma: report of the Third International Workshop. J Allergy Clin Immunol 1997;100(6 Pt 1):S2-24.

2. Ree HI, Jeon SH, Lee IY, Hong CS, Lee DK. Fauna and geographical distribution of house dust mites in Korea. Korean $\mathrm{J}$ Parasitol 1997;35:9-17.

3. Robinson C, Kalsheker NA, Srinivasan N, King CM, Garrod $\mathrm{DR}$, Thompson PJ, et al. On the potential significance of the enzymatic activity of mite allergens to immunogenicity. Clues to structure and function revealed by molecular characterization. Clin Exp Allergy 1997;27:10-21.

4. Yi MH, Kim HP, Jeong KY, Kim CR, Kim TY, Yong TS. House dust mite allergen Der $\mathrm{f} 1$ induces IL-8 in human basophilic cells via ROS-ERK and p38 signal pathways. Cytokine 2015;75:35664.

5. Lee HY, Lee GH, Kim HK, Chae HJ. Platycodi Radix and its active compounds ameliorate against house dust mite-induced allergic airway inflammation and ER stress and ROS by enhancing anti-oxidation. Food Chem Toxicol 2019;123:412-23.

6. Fukunaga M, Gon Y, Nunomura S, Inoue T, Yoshioka M, Hashimoto $S$, et al. Protease-mediated house dust mite allergeninduced reactive oxygen species production by neutrophils. Int Arch Allergy Immunol 2011;155 Suppl 1:104-9.

7. Yoshimura T, Matsushima K, Oppenheim JJ, Leonard EJ. Neutrophil chemotactic factor produced by lipopolysaccharide (LPS)-stimulated human blood mononuclear leukocytes: partial characterization and separation from interleukin 1 (IL 1). J Immunol 1987;139:788-93.

8. Marini M, Vittori E, Hollemborg J, Mattoli S. Expression of the potent inflammatory cytokines, granulocyte-macrophage-colonystimulating factor and interleukin- 6 and interleukin-8, in bronchial epithelial cells of patients with asthma. J Allergy Clin Immunol 1992;89:1001-9.

9. Bellini A, Yoshimura H, Vittori E, Marini M, Mattoli S. Bronchial epithelial cells of patients with asthma release chemoattractant factors for T lymphocytes. J Allergy Clin Immunol 1993;92:41224.

10. Hollander C, Sitkauskiene B, Sakalauskas R, Westin $\mathrm{U}$, Janciauskiene SM. Serum and bronchial lavage fluid concentrations of IL-8, SLPI, SCD14 and sICAM-1 in patients with COPD and asthma. Respir Med 2007;101:1947-53.

11. Mukaida N, Mahe Y, Matsushima K. Cooperative interaction of nuclear factor-kappa B- and cis-regulatory enhancer binding protein-like factor binding elements in activating the interleukin-8 gene by pro-inflammatory cytokines. J Biol Chem 1990;265:21128-33.

12. Mukaida N, Okamoto S, Ishikawa $\mathrm{Y}$, Matsushima K. Molecular mechanism of interleukin-8 gene expression. J Leukoc Biol 1994;56:554-8.

13. Barnes PJ, Karin M. Nuclear factor- $\kappa \mathrm{B}$ : a pivotal transcription factor in chronic inflammatory diseases. N Engl J Med
1997;336:1066-71.

14. Shi J, Luo Q, Chen F, Chen D, Xu G, Li H. Induction of IL-6 and IL-8 by house dust mite allergen Der $\mathrm{p} 1$ in cultured human nasal epithelial cells is associated with PAR/PI3K/NF KB signaling. ORL J Otorhinolaryngol Relat Spec 2010;72:256-65.

15. Bossios A, Gourgiotis D, Skevaki CL, Saxoni-Papageorgiou P, Lötvall J, Psarras S, et al. Rhinovirus infection and house dust mite exposure synergize in inducing bronchial epithelial cell interleukin-8 release. Clin Exp Allergy 2008;38:1615-26.

16. Widmann C, Gibson S, Jarpe MB, Johnson GL. Mitogenactivated protein kinase: conservation of a three-kinase module from yeast to human. Physiol Rev 1999;79:143-80.

17. Sohn MH, Lee KE, Choi SY, Kwon BC, Chang MW, Kim KE. Effect of Mycoplasma pneumoniae lysate on interleukin-8 gene expression in human respiratory epithelial cells. Chest 2005;128:322-6.

18. Lee KE, Kim JW, Jeong KY, Kim KE, Yong TS, Sohn MH. Regulation of German cockroach extract-induced IL-8 expression in human airway epithelial cells. Clin Exp Allergy 2007;37:136473.

19. Monick M, Staber J, Thomas K, Hunninghake G. Respiratory syncytial virus infection results in activation of multiple protein kinase $\mathrm{C}$ isoforms leading to activation of mitogen-activated protein kinase. J Immunol 2001;166:2681-7.

20. Sohn MH, Lee KE, Kim KW, Kim ES, Park JY, Kim KE. Calciumcalmodulin mediates house dust mite-induced ERK activation and IL-8 production in human respiratory epithelial cells. Respiration 2007;74:447-53.

21. Shen GN, Wang C, Luo YH, Wang JR, Wang R, Xu WT, et al. 2-(6-Hydroxyhexylthio)-5,8-dimethoxy-1,4-naphthoquinone induces apoptosis through ROS-mediated MAPK, STAT3, and $\mathrm{NF}-\kappa \mathrm{B}$ signalling pathways in lung cancer A549 cells. Evid Based Complement Alternat Med 2020;2020:7375862.

22. Mata M, Pallardo F, Morcillo EJ, Cortijo J. Piclamilast inhibits the pro-apoptotic and anti-proliferative responses of $\mathrm{A} 549$ cells exposed to $\mathrm{H}_{2} \mathrm{O}_{2}$ via mechanisms involving AP-1 activation. Free Radic Res 2012;46:690-9.

23. Hemilä H, Chalker E. Vitamin C for preventing and treating the common cold. Cochrane Database Syst Rev 2013;(1):CD000980.

24. Hemilä H, Louhiala P. Vitamin C for preventing and treating pneumonia. Cochrane Database Syst Rev 2013;(8):CD005532.

25. Anderson R, Hay I, van Wyk H, Oosthuizen R, Theron A. The effect of ascorbate on cellular humoral immunity in asthmatic children. S Afr Med J 1980;58:974-7.

26. Tongtako W, Klaewsongkram J, Mickleborough TD, Suksom D. Effects of aerobic exercise and vitamin $\mathrm{C}$ supplementation on rhinitis symptoms in allergic rhinitis patients. Asian Pac J Allergy Immunol 2018;36:222-31.

27. Matsukura S, Kokubu F, Noda H, Tokunaga H, Adachi M. Expression of IL-6, IL-8, and RANTES on human bronchial epithelial cells, $\mathrm{NCl}-\mathrm{H} 292$, induced by influenza virus A. J Allergy Clin Immunol 1996;98(6 Pt 1):1080-7.

28. Park Y, Lee H, Lim JW, Kim H. Inhibitory effect of $\beta$-carotene 
on Helicobacter pylori-Induced TRAF expression and hyperproliferation in gastric epithelial cells. Antioxidants (Basel) 2019;8:637.

29. Holgate ST, Lackie PM, Davies DE, Roche WR, Walls AF. The bronchial epithelium as a key regulator of airway inflammation and remodelling in asthma. Clin Exp Allergy 1999;29 Suppl 2:905.

30. Tomee JF, van Weissenbruch R, de Monchy JG, Kauffman HF. Interactions between inhalant allergen extracts and airway epithelial cells: effect on cytokine production and cell detachment. J Allergy Clin Immunol 1998;102:75-85.

31. Trevino JG, Gray MJ, Nawrocki ST, Summy JM, Lesslie DP, Evans DB, et al. Src activation of Stat3 is an independent requirement from $N F-\kappa B$ activation for constitutive IL-8 expression in human pancreatic adenocarcinoma cells. Angiogenesis 2006;9:101-10.

32. Kim YM, Reed W, Wu W, Bromberg PA, Graves LM, Samet JM. $\mathrm{Zn}^{2+}$-induced IL-8 expression involves AP-1, JNK, and ERK activities in human airway epithelial cells. Am J Physiol Lung Cell Mol Physiol 2006;290:L1028-35.

33. Liu R, Bai J, Xu G, Xuan L, Zhang T, Meng A, et al. Multi-allergen challenge stimulates steriod-resistant airway inflammation via
NF-кB-mediated IL-8 expression. Inflammation 2013;36:845-54. 34. Coward WR, Sagara H, Wilson SJ, Holgate ST, Church MK. Allergen activates peripheral blood eosinophil nuclear factorkappaB to generate granulocyte macrophage-colony stimulating factor, tumour necrosis factor-alpha and interleukin-8. Clin Exp Allergy 2004;34:1071-8.

35. Osterlund C, Grönlund H, Polovic N, Sundström S, Gafvelin G, Bucht $A$. The non-proteolytic house dust mite allergen Der $p$ 2 induce NF-кB and MAPK dependent activation of bronchial epithelial cells. Clin Exp Allergy 2009;39:1199-208.

36. Pan HH, Hsiao YP, Chen PJ, Kang YT, Chao YH, Sheu JN, et al. Epithelial growth factor receptor tyrosine kinase inhibitors alleviate house dust mite allergen Der p2-induced IL-6 and IL-8. Environ Toxicol 2019;34:476-85.

37. Pulsawat $P$, Soongrung $T$, Satitsuksanoa $P$, Le Mignon $M$, Khemili S, Gilis D, et al. The house dust mite allergen Der $p 5$ binds lipid ligands and stimulates airway epithelial cells through a TLR2-dependent pathway. Clin Exp Allergy 2019;49:378-90.

38. Zhang Y, Tang HM, Liu CF, Yuan XF, Wang XY, Ma N, et al. TGF- $\beta 3$ induces autophagic activity by increasing ROS generation in a NOX4-dependent pathway. Mediators Inflamm 2019;2019:3153240. 